\title{
Clinton's science adviser embroiled in 'book-burning' row over risk bill
}

Washington. In an unprecedented move that reflects the increasing politicization of US science policy, the chairman of the House of Representatives Science committee has complained to President Bill Clinton that his science adviser, Jack Gibbons, has been engaged in "mudslinging and namecalling", and has asked the president to take appropriate action.

The complaint has come from Robert Walker (Republican, Pennsylvania), in a letter written to Clinton on 17 July. It was prompted by a press briefing on environmental research at which the normally mildmannered Gibbons described Republican proposals for including more explicit risk assessment in environmental legislation (see Nature 373, 180; 1995) as "the scientific equivalent of book-burning".

Walker is a major force behind the risk assessment proposals, which are at present stalled in the Senate. In his letter, Walker wrote that "in recent weeks, certain officials have gone well beyond the bounds of legitimate policy debate and have entered into a particularly despicable type of mud-slinging and name-calling".

$$
\text { Walker adds: }
$$

"the only 'bookburners' with which I am familiar in recent world history were the Nazi Party fanatics of Hitler's Germany". He describes the equating of "those who have a legitimate political Walker: asking Clinton difference with to ensure 'civility'. your administra-

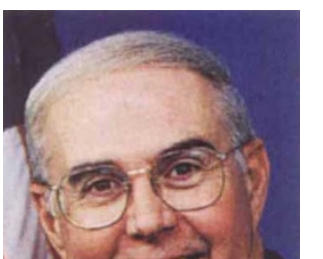

tion" with Nazis as both "personally highly offensive and totally unacceptable".

He concludes: "I trust you will take

\section{Grants continue despite planned closure}

Washington. The US National Institute of Standards and Technology (NIST) plans to announce a series of new awards under its Advanced Technology Program (ATP) within the next few weeks - despite the wish of Congress to close down the controversial programme.

NIST will grant eight fresh batches of ATP awards between now and September, most of three years' duration. According to Brian Belanger, deputy director of the programme, it will do this in order to "fulfil its obligation" to industrial partners that have already invested time and money in preparing proposals.

But Republicans in the House of Representatives, who are proposing that the ATP be closed in October, are furious. "NIST is making a terrible mistake by spreading money out on new contracts," says Robert Walker (Republican, Pennsylvania), chairman of the House Science committee.

NIST is required to meet commitments under its contracts only if the money to do so is duly appropriated by Congress. Walker predicts that NIST, having started these contracts, will now come back to Congress next year, pleading for money to finish them.

But he describes NIST's granting of new contracts as "a horrible decision" that will cost the agency support in Congress. "They ought to be reserving money so they can complete the contracts they [have] already [signed]."

Last month, NIST awarded grants to 17 projects for new technologies in all fields, and another seven to help develop tools for DNA analysis, at a total cost of \$61 million. By September, the agency will announce the winners of competitions for grants in another ten specified fields, ranging from catalysis technology to digital data storage; these involve about $\$ 150$ million of NIST investment in the first year alone.

Even after a \$90-million cut in a rescission bill signed by President Bill Clinton last month, NIST still has \$341 million to spend on ATP in the financial year which ends October. Clinton has requested $\$ 491$ million for the programme next year; the House appropriations committee wants to cut out all of this, while the Senate will put forward its own figure after the August recess.

The conflict between the Democrat administration and the Republican Congress over the ATP is one of an array of policy and budget issues that will be finally resolved in October, when the two sides must agree on a budget bill. The granting of new ATP money is intended to indicate the administration's determination to maintain the programme.

But Clinton did not block cuts to the ATP when he made compromises last April, and some of the its keenest supporters doubt he will fight for it. C. $\mathbf{M}$. immediate steps to ensure that all members of the White House staff heed your own ground rules on 'civility', and that those responsible for such unseemly public statements are appropriately counselled."

The letter appears to mark a new low in the deteriorating relations between Democrats and Republicans on science policy, an area once relatively immune from partisan politics. Democrats who have seen the letter accuse Walker of hypocrisy; with his close friend Newt Gingrich, now the leader of the House, Walker developed a fearsome reputation in the previous Congress for his mastery of techniques of political manipulation.

But the letter, which has not been released by either Walker's staff or the White House, does not seem to have been a publicity stunt. Walker is known to have been angered by several of Gibbons' pronouncements this year, in particular a highly partisan speech delivered to a packed policy seminar held by the American Association for the Advancement of Science (AAAS) in April (see Nature 374, 667; 1995).

Gibbons' line on book-burning isn't even a fresh one: it was used last February, just as provocatively but less surprisingly, by Bruce Babbitt, the Secretary of the Interior, in a combative speech on Republican plans to close the National Biological Service (see Nature 373, 646; 1995).

Many observers have been startled at Gibbons' recent partisan tone. Some speculate that he is deeply angered by Republican moves to shut down the Office of Technology Assessment (OTA), of which he was director for 13 years before he moved to the White House in 1993. Protocol has prevented Gibbons from defending OTA, which is an office of Congress.

Gibbons' job as both Clinton's science adviser and director of the White House Office of Science and Technology Policy has changed drastically since Republicans took control of Congress last November. Before then, he was helping to run the country, coordinating science policy through innumerable back-room meetings. Now young, clean-cut Republican congressional staff are running the country, and Gibbons has had to join Walker and Gingrich in the political bear-pit, fighting to put over sound-bites.

A spokeswoman for Walker says that he and Gibbons still have "very friendly personal conversations", and that Walker's objection was to the science adviser's "public rhetoric". The normally communicative White House press office did not return calls on the subject, possibly indicating a reluctance to engage in further public squabbling with Walker. Colin Macilwain 